\title{
A Historical Discourse on Tithing and Seed Sowing in some Nigerian Pentecostal Churches
}

\author{
Rimamsikwe Habila Kitause ${ }^{1}$ Hilary Chukwuka Achunike ${ }^{2}$ \\ ${ }^{1}$ Ph.D Student, Department of Religion and Cultural Studies, Faculty of the Social Sciences, University of \\ Nigeria, Nsukka, Enugu State, Nigeria \\ ${ }^{2}$ Professor, Department of Religion and Cultural Studies, Faculty of the Social Sciences, University of Nigeria, \\ Nsukka, Enugu State, Nigeria,
}

\begin{abstract}
Nigerian Pentecostal theology of prosperity has always been built around Tithing, Offering and Seed sowing with the attendant spill over effect on the mainline churches becoming more captivated in the practice. Even within the Pentecostal circles, the neo Pentecostals are steadily exerting a great deal of influence on the classical Pentecostals by enticing some of them to start preaching prosperity in the manner that the neo Pentecostals do. This article employs oral interview as well as phenomenological and expository approaches in its studies. It is discovered that prosperity preaching is currently becoming an important religious phenomenon in the Nigerian religious landscape leading to the skyrocketing of prosperity churches in contemporary Nigeria. The article submits that it is high time those who preach prosperity in Nigeria maintained a balance between their prosperity emphasis and salvation messages for the sake of people's souls.
\end{abstract}

Keywords: Offering, Prosperity, Pentecostal, Seed sowing, Tithing

\section{Introduction}

Christianity is a religion that has several obligations and responsibilities. Christians generally observe these religious rites dutifully as demonstration of their faith in God as well as to satisfy their individual aspirations. Down through the ages Christians are taught that God's blessing can be accessed through various means. In Nigeria today, the subject of prosperity seems to be a pivotal point which is being promoted almost to the total neglect of other scriptural themes. This emphasis on prosperity appears to be more pronounced within the Pentecostal circles than it is in the mainline churches (Ibenwa, 2012) [1].

As a matter of fact, Nigeria is relatively having a depressed economy. Some Pentecostal pastors have been accused of being money minded and not preaching pure Gospel. In Nigeria, many Pentecostal pastors lead flamboyant lifestyle. The churches are attractive in structure and style. Some of the churches are structured in the most architectural technology. Money is therefore needed to run and maintained the church structures and the many personnel employed to work within the church, including the pastor's lifestyle. Added to this is the fact that many Pentecostal churches have established kindergarten, primary, and secondary schools. They have gone ahead in recent times to establish universities. All these need money to be taken care of. Therefore, tithing and seed sowing become a necessity in the Nigerian Pentecostal churches. The mainline churches are not an exception. Some of them are fast imitating the Pentecostals in tithing and seed sowing. It may equally be interesting to mention that mainline churches believed prosperity to be God's induced but do not over emphasis it.

The Pentecostals teach that prosperity is the covenant rights of all born again Christians which is dependent upon their obedience to the basic lay down principles for prosperity. The Pentecostals believe that God identifies with and blesses Christians who faithfully keep their own part of the covenant for blessing. According to Achunike (2007), "The Nigerian religious space has been inundated by this form of preaching such that youths seem to believe in prosperity without hard work" (p.83) [2].

The pertinent questions to ask are: Do all those who carefully fulfil prosperity principles as taught and spread by the Pentecostals actually come by the proportionate breakthroughs? Do all Pentecostal tithers and seed sowers really experience some more blessings quite above those who do not obey? What explanations are there for the fast expansion of prosperity churches in Nigeria?

It may not be an exaggeration to state that some Pentecostal churches in Nigeria are making great waves than other church persuasions due to their sudden shift from asceticism to materialism. It is equally most probable that some neo Pentecostal churches in Nigeria known for prosperity preaching especially the Living Faith Church (The Winners Chapel), and the likes are either directly or indirectly exerting some influence on the classical Pentecostals at the moment. They seem to be overtaking the classical Pentecostals like the Assemblies of God Church, Nigeria in terms of proliferation and numerical explosion (Nnamani, 2007) [3]. It is speculated 
that the classical Pentecostal churches are losing their members to prosperity churches in Nigeria. How this happens is what this paper is set out to investigate.

This paper therefore attempts to unravel the facts behind this recent development in Nigeria especially as it is connected to Pentecostals' sudden reawakening of interest in tithing and modern creation of seed sowing, a Pentecostal preoccupation to unleash prosperity for all. It is an irenic study which explores the manner in which the Pentecostals of Nigeria go about tithing, offering and seed sowing in three different popular Pentecostal churches in Nigeria. The study is carried out in the Living Faith Church (The Winners Chapel), The Redeemed Christian Church of God (The RCCG) and the Assemblies of God Church, Nigeria. The paper tries to ascertain the degree to which this practice of tithing and seed sowing have infused and influenced the Nigerian religious environment with its attendant impacts on the nation, churches as institutions, presidents or founders of these churches as well as the laity in Nigeria.

To begin with, the conceptual clarification of some key terms in the article becomes very expedient. The paper traces the biblical, historical and contemporary origin of tithing and seed sowing in Christendom. It equally discusses how the three Pentecostal churches under study practice tithing, offering and seed sowing in their respective church settings. It analyses the benefits and consequences of tithing and seed sowing which appears to the Pentecostals as the most important religious phenomenon in the Nigerian Christianity today. The paper evaluates the Pentecostal practice of these obligations.

\section{Conceptual Clarification of Terms.}

In trying to do justice to this discussion and aid more understanding, clarification of concepts like tithing, offering and seed sowing becomes imperative.

\subsection{Tithing}

The term tithing emanates from the noun 'Tithe'. Tithe is a tenth part of one's income, especially when donated to the church (Watkins \& Watkins, 1992) [4]. It is the tenth percent of one's increase, profit or earnings (Inyama, 2003) [5]. According to Oyedepo (2010) "Tithing is a systematic release of a tenth of all your increase to God" (pp.152-153) [6]. He reiterates that tithe is a special portion of your increase which God has reserved for Himself. Tithing is further defined as the practice of giving one-tenth of one's income to God (Redeemed People's mission Inc, 2003) [7].

\subsection{Offering}

Offering is something offered, especially to God. In Hornby (2006) [8], it is seen as something that is given to God as part of religious worship. Offering is not the same as tithing. Offering is a kind of wilful giving after payment of tithes. Ball (2003) asserts that "As New Testament believers, our giving really only begins after we have tithed to our local church" (p.23) [9]. Offering is therefore "a love gift" to God (http:www.ask.com/answer/10233161) [10].

\subsection{Seed Sowing}

Seed sowing is a coinage that has other nomenclatures like "seed faith", "seed of faith". This article alternates the use of these terms ewfor convenience. Sowing is the planting of seeds (en.wikipedia.or/Wikipedia/sowing) [11]. Sowingd seeds of faith is about offering seeds of encouragement and hope (http://www.sowingseedsoffaith.com/) [12]. Roberts (1970), expatiates the idea of seed faith based on Luke 6:38 thus:

We should make our giving of money as seed. Seed - money is thanking God in advance. It is like the grace you say before meal... It is an act of seed - planting, an act of faith of expecting a return just as the farmer does at harvest time (p.30) [13].

In other words, what this citation implies is that whatever is given or sown as seed to God as seed faith is received back from God in the future. Therefore, seed sowing is seed giving. This signifies that everything you give to God is given out as seed. When one gives ones should expect a miracle. Roberts (1985) caps it up with these words: "You can attack your lack by giving... and by expecting to receive back from your giving" (p.13) [14].

Adeleye (2011) understands Roberts' seed faith principle to include "Our tithes and offerings" (p. 82) [15]. But there is a contrary opinion to this. It is held that tithing and seed sowing are not one and the same. They are said to be different altogether and should not be lumped as one thing. This is expressed thus:

We have to be very careful when it comes to tithing and seed sowing. Our tithes belong to God. We are protected and blessed through tithing, but tithing is not the same as seed sowing. You will reap what you sowed. When you sow seed, name your seed in faith. Remember that we are not supposed to wait until we see a physical manifestation, and then believed God. We 
are supposed to believe before we see (http://www.Docities.org/mikespieceofheaven4.htm) $[16]$.

As can be deduced, there are divergent views about seed sowing. People's conception about it differs greatly. But the general opinion is that tithing and seed sowing are two different things. It is therefore informative to note that the manner of this practice among the Pentecostals in Nigeria reveals this general perspective of seed sowing.

\section{Biblical Origin and Development of Tithing}

Historically speaking, the practice of tithing and perhaps offering predates the giving of the law. The first recorded instance of tithing in the Bible occurs in Genesis 14:17-20. Here Abraham is reported to have paid tithes of all his booty to Melchizedek, the king of Salem; the priest of the Most High God. Thereafter, Jacob imitated his progenitor and covenanted the tenth of all his proceeds to God (Gen.28:22).

In Mosaic Law, God declared as sacred "The tenth of all produce, flocks and cattle" which are to be offered to Him (God)", (Unger \& Harrisons, 1988, p.1290) [17]. "And all the tithe of the land, whether of the seed of the land, or the fruit of the tree, is the Lord's. It is holy unto the Lord..." (Lev. 27: 30-32). During this epoch, the Levitical system was in place, and the Levites, who were God's ministers as at then were catered for through the tithes of the Israelites as recorded in Num. 18:21-24 (Douglas \& Tenney, 1987) [18].

In the times of the kings and prophets in Israel, tithe payments were still enforced. According to Kumuyi (1998):

Whenever good kings who kept Israel in true worship of God reigned in Israel, the practice of tithing was upheld and the Priest and Levites were provided for. Whenever the nation forgot to obey God fully, the prophets were sent with a message of rebuke, correction and instruction to bring them back to full obedience (p.76) [19].

In the New Testament, during the Early Church era, there seems to be no practice of tithing. The church then is said to be under constant state of jeopardy as a result of fierce persecution by Jewish authorities. This made the infant church to probably resort to embracing communism, a practice which made Christians then to willingly contribute to the common purse, thus enabling all brethren to having and sharing all things in common (Acts 2:44-45). It is probably in close connection with this that Lindsay (1996) affirms that "For the above reason, tithing was not practiced during the first few years of the Early Church simply because the people did not have their separate homes, and they gave all that they had to the Church" (pp.33-34) [20]. This practice of communal living was short-lived because in the view of many including those of the present writers, it was probably a child of circumstance and emergency.

\section{Historical Evolution and Practice of Tithing in Christendom}

It has been established that the Early Church had no tithing system even though tithe has been in existence in the form of religious tax. As a tax, it was required by law for every person to pay a tenth of his income to the church for multi-purpose use (Mills 2009) [21]. In the course of time, Irenaeus and Origin treated tithes with contempt considering it as a Jewish custom, something not required of Christians.

According to Nwokoro (2007), after the apostolic era, it was difficult to maintain the church and this probably made the Early Church fathers to "Sought for means to revive the tithe as means of supporting the church and financing it" (p.30) [22]. It is with regard to this that someone writes:

But as the church expanded and its material needs grew more numerous and complex, it became necessary to adopt a definite rule to which people could be held either by a sense of moral obligation or by a precept of positive law. The tithing of the old law provided an obvious model, and it began to be taught -more commonly in the West, however, than in the East- that the faithful should give tithes of their income (Dietlein, 1967, p. 174) [23].

History has it that when this view of tithing began to get sufficient support, it found legislative expression. The Council of Macon in AD 584 is reported to have ordered payment of tithes and threatened ex-communication to those who refused to comply. Other local councils follows suit with similar enactment. But as it appears, the beginning of tithing was punctuated with some irregularity and reluctance in Christendom. It was not until AD 785 precisely toward the end of the $8^{\text {th }}$ Century as records show that Charlemagne promulgated a decree and signed the compulsory payment of tithes into civil law. This was followed by a declaration by the Council of Trent that it is only to God that tithe should be paid and defaulters of tithes must make restitution fully before being absolved by the church. As it happened, during the secularization of the State that came after the reformation of the church, the tithing system became unworkable and the French Revolution brought tithing practice to an end in the Roman Catholic Church (Dietlein, 1967, p. 175). It is necessary to go down memory lane to recall that it was from the Roman Catholic Church that the Anglican Church and some of the churches in existence now seceded after the reformation. This is excluding the Greek Orthodox Church in the East. Recorded history indicates that after the reformation, the reformers restored true Bible teachings and probably 
reinstated the tithing of one tenth in the protestant churches while the Catholics Church appears to remain without the practice of tithing since then up to now. The protestant churches have since the reformation observed tithe payment which is ongoing in the Pentecostal churches with varying degree of emphasis especially in Nigeria. Interestingly, all the charismatics practice faithful payment of tithe as a religious duty (C.Idoko, Personal communication, May 22, 2013).

\section{The Genesis of Seed Sowing}

Many Christians across the globe seem to have no difficulty accepting the Biblical teaching and practice of tithing and offering. What probably seems to be in doubt, which lacks wide acceptance is the Pentecostals' theology of Seed Sowing. Be that as it may, a clearer understanding of this seed sowing requires a closer examination of its genesis in Christendom.

There is yet not enough historical evidence as to when exactly the Christian practice of Seed sowing began. But there appears to be a general consensus among scholars that the practice likely crept into the religious arena with the Word Faith Movement sometimes between the $19^{\text {th }}$ and $20^{\text {th }}$ centuries (Walter, 1997) [24]. The Word Faith Movement known otherwise as the Faith Movement or Word, Faith-Formula, Word of Faith, Hyper Faith, Positive confession, Name it and claim it or Health and wealth gospel and prosperity teaching has prominent personalities like Kenneth Erwin Hagin, Kenneth and Gloria Copeland, Oral Robert, Robert Tilton, Charles Capps, Frederick K.C. Price, John Avanzini among several others as its proponents (MacArthur, 1992) [25].

It is held that the cardinal teaching of these prosperity exponents is that "God wants believers to be rich and enjoy good physical health" (Mumford, 2012, p.12) [26]. In their opinion, for believers to realize abundance wealth and good health, they need only believe in the promises of God and be obedient to God's word. It is on record that prosperity gospel all started in America. According to Okwori (1995), "American prosperity gospelers are the mentors to those in other parts of the world" (p.17) [27]. He stresses that America is both the mentor and converging point for the prosperity gospel the world over.

In tracing the historical roots of the Faith Movement, Okwori (1995) identifies the philosophic influences of the $19^{\text {th }}$ century coupled with what he acknowledged as "The Three Waves of Pentecostalism, the Faith-prosperity movement and the Signs and Wonders movement" (pp. 21-25). These antecedent occurrences to his mind is said to have precipitated and birthed the historic prosperity gospel in the United State of America (USA). From all indication, it is said that Kenneth E. Hagin is the globally recognized father of the Modern Faith Movement (Hummel, 1991) [28]. Hagin is reported to have been heavily influenced by the teachings and writings of Essek William Kenyon, a Gospel minister, whose ordination took place at the Methodist church but who spent most of his life time with the Baptist church, who primarily, as history indicates articulated and documented the essentials of prosperity theology (McIntyre, 1997 [29]; McConnell, 1995 [30]).

As proved by Hummel (1991), "It was Kenyon's books that have the greatest influence on the Faith Movement over the years" (p. 8).

As it happened, while a student at Christ for the Nations Bible Institute in USA, Benson Andrew Idahosa, a Nigerian, was influenced by the various purveyors of the prosperity preaching in the USA (Onwu, 2006) [31]. In his observation, Adeleye (2011) concurs that "The greatest influence on the emergence of the prosperity gospel in Nigeria is Oral Roberts whose teaching was embraced and taught by Bishop Benson Idahosa - the undisputed father of the prosperity gospel in Nigeria"(p. 81). Okwori (1995) adds that Benson Idahosa has always been fondly referred to as 'Papa' by his followers and is a mentor to all or almost all other Nigerian advocates. Idahosa is noted to be a rallying point for the rest of the Nigerian prosperity protagonists. Prominent among them is Bishop David Oyedepo, who is currently championing the course of prosperity preaching in Nigeria (Achunike, 2007).

Oral Roberts' influence in Nigeria along with others is remarkable. According to Hummel (1991), Roberts "Popularized Seed-Faith giving which guarantees that donors will soon reap rich returns on their investment" (p.16). Oral Roberts' seed-faith principles is based on a thought that "Whatever you can conceive, and believe, you can do" (Roberts, 1970, p.11). He has been declared the originator of seed-faith. Roberts (1970) speaks about his conviction succinctly:

The idea of SEED-FAITH was born in my heart that day when I saw that everything God does starts with a seed planted. Remember, only what you give can God multiply back. If you give nothing, and even if God were to multiply it, it would still be nothing (p.30).

His anchor scripture for the doctrine of seed-faith is Gen. 8:22 which says "As long as the earth endures seedtimes and harvest, cold and heat, summer and winter, day and night will never cease".

\section{Tithing, Offering and Seed Sowing in Pentecostal Churches in Nigeria}

The Nigerian Pentecostal prosperity preachers teach that the promise of prosperity from God to the nation of Israel in the Old Testament applies to all Christians in the New Covenant (Pam, 2012) [32]. They teach 
that prosperity is a matter of giving out cheerfully and making positive confessions. Good health and wealth to their minds does not just come graciously, it takes sowing the "Seed of faith".

To the Pentecostals, as Ibrahim (2013) observes:

To "sow a seed" is to donate money generously through the faithful payment of tithes and offering to their ministries in order to reap the harvest in the future. Offering times is often called "blessing time", with the exhortation that those who give bountifully will receive bountifully and those who give sparingly or refuse to give will face threatening curses. The more the seed, the more the harvest (p.18) [33].

Ibrahim adds that to the Pentecostals, God is a "money multiplier". How tithing, offering and seed sowing are practiced in the Pentecostal churches in Nigeria is really captivating and inviting.

This paper, at this juncture, attempts to carefully x-ray, discuss and document the different approaches and emphases in the manner in which tithing, offering and seed sowing are done in the following three Pentecostal churches in Nigeria. These include: The Winners Chapel, The RCCG and the Assemblies of God Church, Nigeria. This is to avoid the temptation of repeating or describing unintelligently the same process of tithing, offering and seed sowing in all the three respective churches under surveillance.

\section{The Living Faith Church World-Wide}

The Pentecostals hold strongly to the Biblical principles of prosperity. The Living Faith Church, founded by Bishop David Olaniyi Oyedepo in 1982 is not left out in the business. At present, it seems that the Living Faith Church appears to be the leading neo Pentecostal church in Nigeria that preaches prosperity uncompromisingly. Oyedepo is a direct disciple to late Archbishop Benson Andrew Idahosa (1939-1998), the architect of Nigerian prosperity gospel (Ojo, 2012 [34]; Emeka, 2002 [35]). Oyedepo (2008) testifies about his prosperity mandate to Nigerians:

I was away in the United States of America in the summer of 1987 for a series of speaking engagements when I had a unique encounter with God in my hotel room which culminated in the delivery of another mandate. This was in the early hour of August 26, 1987. While getting out of bed to begin my morning devotion, the Spirit of the Lord spoke clearly to me: "Arise get back home and make my people rich"...This is the root of the prosperity message of this ministry and the proofs are all around today (p. 21) [36].

Just like the Apostle Paul, Oyedepo did not hesitate to obey the heavenly mandate of making God's people rich. He believes that his primary call and mission is to enrich people by eradicating their poverty (Adeleye, 2011). It is re-echoed that Oyedepo, combining all he has learnt from his mentor, couple with his own creativity, has not only expanded the Winners Chapel locally and internationally, but has outsmarted the other prosperity preachers in Nigeria, thus becoming the leading champion in prosperity preaching in Nigeria. Oyedepo (1995) admonishes his members thus: "The knowledge and practice of the truth opens every prison house that has locked you in. It takes knowledge to become free from sweat. Not all Winners sweat to win. Sweating is a curse. It symbolizes struggles" (p. 81) [37]. In order to create financial empire for himself and his followers in his bit to fulfilling the prosperity mandate, it was incumbent upon Oyedepo to teach the basic rudiments of all-round breakthrough that releases wealth and setting everyone free from poverty and hardship. This, the paper discusses right away.

7.1 Tithing and Offerings in the Winners Chapel

Tithing is a command from God, and is the master key to enjoying financial miracles (Oyedepo, 2008). It is said to be the tenth part of whatever increase a person enjoys. It is taught that tithe does not belong to anyone but to God. Tithing is therefore seriously emphasized in the Living Faith Church as one of the major tenets of Christianity.

Tithe payment is compulsory for the Living Faith members. It is used as a yardstick to ascertaining committed members of the Church. No one is exempted from paying tithes - ministers, house wives, children, students, and the unemployed (Adjeman, 1995) [38]. Anyone who does not pay tithes is said to be robbing God directly. Adjeman(1995), one of the senior pastor of the Church speaks on this "Stealing is different from robbing. To rob means applying force to take that which does not belong to you... One steals when no one can see. You rob in the presence of the victim" (pp.3-4).

According to Oyedepo (2008), tithing is an inescapable covenant obligation. "Giving is the key to receiving Heaven's increments. Without it, God has no access to you, because His law states that there can be no harvest without first planting a seed" (Oyedepo, 2010, p.84 [39]). God's rain of plenty is released on people on the basis of their insight into the workings of the covenant of blessing (Oyedepo, 1997) [40]. By this, it is meant that those who do not pay their tithes cannot escape poverty. This is because, overflowing abundance is by giving. Tithing in the opinion of Oyedepo is insurance against destruction in whatever form. Oyedepo is reported to have assured his followers that if "They do not pay their tithes, they will be harassed by devourers: 
frequent car breakdowns, losses, sickness and so on are all manifestations of the devourer" (Adeleye, 2011, p. 93).

The leadership of the Winners Chapel frown against anonymity in tithe payment. Tithes collected during every meeting from members are properly documented in a ledger (E. Finlack, personal communication, May 6, 2013). Tithers are provided with tithe booklets in which every person records the detail of every tithe paid either weekly or monthly and drops same alongside the normal offering. As practised in most Pentecostal churches nowadays, offerings and tithes are being promoted with short exhortation before they are offered (Ugwueye, 2002) [41]. Scriptures like Luke 6:38, Acts 20:55 and Mal. 3:10 featured frequently during promotion of same.

In the Living Faith Church, different types of offerings are raised or collected. These include: (i) Freewill offerings: It is the general offerings that is given in church on Sundays and other service days in worship of God (Oyedepo, 2008). (ii) Kingdom promotion offerings: These are offerings "given for the promotion of God's work on earth" (Oyedepo, 2007, p.152) [42] (iii) Prophetic offerings: they are given to God's anointed messengers/prophets/spiritual fathers to provoke prophetic utterances cum blessings from them (Oyedepo, 1995), (iv) Needy offerings: Needy offerings are collected for the purpose of taking care of the poor which is an opportunity for members' rising economically (Oyedepo, 2005) [43]. (v) Sacrificial offerings: they are offerings sown in tears by members "For turning their financial captivity for the purpose of building the Church" (Oyedepo, 2007, p.34) [44]. (vi) Thanks giving offerings: A special offerings for an answered prayer or a special breakthrough or deliverance of any kind.

7.2 The Living Faith Church and Seed Sowing

Seed sowing is probably becoming an important coinage as well as practice among Nigerian Pentecostals. According to Adeleye (2011), "Oyedepo has fully embraced Oral Roberts seed-Faith Concept" (p. 93). 'Seed' in this context is 'money' (Roberts, 1970, p.30; Murdock, 1998, p. 96 [45]). Roberts sustains that when you sow seeds expect a miracle. Idahosa (1998) expresses thus "Man counts the fruits, but God counts the seeds" (p. 64) [46]. To Oyedepo (2010) "There is no fruit without the seed. It is firstly the seed, and then, the harvest" (p. 21) [47]. Ukpai (2011) shares the same views when he said that "Prosperity is impossible without a seed... You must sow a seed for that is the secret of prosperity" (p. 30) [48].

The Christian practice of seed sowing seems to have come to stay among Nigerian Christians especially the Pentecostals. Members of the Living Faith Church are well informed about its efficacy and outworking. Many are keying into it. It has become one of the major sources of revenue generation for the church at the moment.

The principle of seed-faith is applied when a person is confronted with seemly insurmountable problem that has defied all solutions. It is applied when a person has a need or wants a breakthrough in any life challenge, then; one sows a seed-of-faith to a "man of God" in requesting his prayers, specifically for the need in question. The sowing of seed goes with naming the seed in faith that is attaching the seed to a particular problem that demands a solution. It is believed that such "anointed prayers" of the "man of God" will address the problem squarely. Similarly, seeds are sometimes equally sown towards a particular project in the church to provoke certain blessing.

According to Oyedepo (2004) "Destiny is all about investment. Only those who accept responsibilities earn dignity" (p.164) [49]. He adds that "If you are not a giver, prayer cannot open your heavens" (Oyedepo, 1997 , p.74). It is stressed that people need to give to enjoy kingdom prosperity. For "Giving is living" (Oyedepo, 2011, p. 91) [50]. It is "The covenant secret card for supernatural turnaround" (Oyedepo, 2008, p.519). In seed sowing, quality matters. "The quality of seed determines the quality of your harvest" (Oyedepo, 2007 , p.194). God is said to be rating all giving. That He rates your giving in proportion to what He has blessed you with.

Generally, Oyedepo (2007) stresses that all seeds sowing must be done with the following attitudes in mind: (i) Sow willingly, (ii) Do it cheerfully, (iii) Give bountifully, (iv) Give in faith and (v) Give tirelessly. Having done this it is emphasized that there is the need for the one who has sown to water the seeds continuously by confessing positively the right words (Oyedepo, 2004) [51]. Then "Talk your life into the miraculous...Talk prosperity and you will be prosperous" (Oyedepo, 2010, p.70). This is said to be a life of faith which is the master key to a breakthrough. Mills (2011) speaking similarly along this line, clarifies that "Name it, claim it and take it, is simply a descriptive term for exercising your faith. Every Christian must have faith and must exercise it! Faith is the reason for answers to prayer" (p.1) [52]. As observed, most Oyedepo's followers are living out his teachings. They believe that as Winners, lack or misfortunes is not their portion in this life.

They are always positive about life and live as optimists. They maintain language of faith, believing that people who have faith are more prosperous than those who do not have. Though, they often are full of faith expressions and acts, but it seems that "Those exercising of faith" are only mostly for the material blessings and the here and now earthly treasures. 


\section{The Redeemed Christian Church of God (The RCCG) and Her Giving}

In discussing this, the question that really pops the mind at this juncture is: What aspects or emphasis of tithing, offerings and seed sowing in the RCCG that catches attention readily which is quite different from the ones already deliberated above in the Living Faith Church? This inquiry is important in that it helps to avoid unnecessary repetition in the paper. It appears indubitable that all Pentecostal churches in Nigeria preach prosperity. While some preach prosperity to the core without moderation, others sermonise it with caution in view of their holiness background and consciousness. The RCCG falls under the second category. The Redeemed Christian Church of God was "Founded on the tripod of prayer, holiness and evangelism" by the Reverend Josiah Olufemi Akindayomi in 1952 (The RCCG, 2011, Holy Ghost Congress, p.11) [53]. Today, Pastor Enoch Adejare Adeboye oversees the church globally after the demise of the founder.

\subsection{Tithes Payments and Offerings in the RCCG 8.1.1 Tithing}

Tithing is probably one of the key sources of income in Pentecostal churches in contemporary Nigeria. It is being upheld alongside other offertory in the RCCG to be among God's method of prosperity for the people. According to Adeboye (2003):

Anyone who is not paying his or her tithes fully is not going to Heaven. Some people have taught you that if you do not pay your tithes, God will not give you blessings. This is true, but a little more serious. You do not pay your tithes; you do not go to Heaven. Why? Because there are no robbers in Heaven. The Bible calls those who do not pay their tithes robbers in Mal. 3:8 (p. 44) [54].

It is evident from this assertion that the emphasis on tithing in the RCCG is not only for the material blessings of the people, but for them to be able to make it to Heaven. In the RCCG there seems to be a shift in the emphasis about tithing. The focus is for members to consider tithing as both a passport to Heaven as well as source of their earthly prosperity. This posture of the RCCG may not be unconnected to the church's foundation on holiness.

Be that as it may, Ukpong (2008) observes that:

The principle of tithing as an essential requirement to make Heaven Shows how important the issue has become in the Redeemed Christian Church of God in particular and Nigerian Pentecostalism in general. Tithing is not practiced only by the RCCG but the temptation to consider tithing as a passport to Heaven, and source of earthly wealth is definitely not in harmony with the religious sensibility of many Christians (p.130) [55].

However the concept of tithing is understood in Christendom; it is being propagated in the RCCG that "Paying of tithes, is not a sacrifice, but an act of returning to God what He has given you that belongs to Him. It is not optional" (The RCCG, Believers Class Manual, 2003, p.43) [56]. In view of this, "Regular payment of tithes and offering is obligatory because it is God's command" (The RCCG, Baptismal Class Manual, 2011, p. 21) [57]. It is therefore "A duty for all born again children of God to pay their tithes" (The RCCG, Sunday School Teacher's Manual, 2009, p.129) [58]. As if to support this position, Adeboye (2011), writes that:

Those who will get blessing from God will have to go beyond ordinary giving of offering, or paying of tithes. Daily they look for an opportunity to do something special to God that will compel Him to do more than what He wanted to do for them. Those who Trade with God never lose (p.53) [59].

It is on the basis of the above that Adeboye (2005) [60] reiterates that every initial act of giving to God can only take one to a level of financial breakthrough, but persistent giving will lead one to the level of ultimate financial breakthrough. Hence, anyone having financial problems should check how he or she has been obeying God financially (Adeboye, 2000) [61].

\subsubsection{Offering}

Generally, in the RCCG, offerings are collected in every of their meeting which is taken to be another opportunity for their material blessing. For Sundays, different offerings feature, though not all of them may be taken every Sunday. These offerings include: (i) Sunday love offering - is the normal Sunday free will offerings, (ii). Welfare offering - also known as needy offering. (iii). Mission offering - for missionary work. (iv). Church development/project offering - for church expansion. (v). Thanksgiving offering - in appreciation to God of His numerous blessing, given by individuals, group or the entire church.

\subsection{First Fruits and Seeds Sowing in the RCCG 8.2.1 First Fruits:}

First fruit is not categorized under offering, tithes and seed sowing. It is on its own and is placed above tithes in the RCCG. It needs some brief elaboration here. What is first fruit? Adeboye (2002) explains that: 
If you get a new job, the first salary is called the first fruits. If you are a contractor and your company gets a contract, the profit on that contract is a first fruit. If at the beginning of the year there is an increment on your salary, the increment on the first month is the first fruit (p.73) [62].

First fruits are said to be in two categories: (i) First fruit sacrifice and (ii) First fruit of increase. First fruit of increase refers to all increase which includes increase in salary, revenue, crops, and profit etc Prov. 3:9-10, while first fruit of sacrifice involves the whole first income or the lump sum (The RCCG 2011 Training Weekend) [63]. The benefits of releasing first fruits are said to be twofold (i) Divine lifting and (ii) Divine visitation.

\subsubsection{Seed Sowing}

Seed sowing principle is also observed in the RCCG, but under different nomenclature. Here, it is known as Covenant offering. The idea is that a person may covenant a seed with God in order to harvest some blessings. According to Adeboye (2002), "Sowing is different from giving. You sow specifically in order to reap specifically" (p.71). Prince (1986) corroborates that "Giving is sowing in God's harvest field" (P.90) [64]. So it is maintained that "God is committed to supplying and multiplying the resources of those who give" (Fomum, 1988, p.30) [65]. Hill (2002) submits that "Giving is a part of holiness... No person could claim to live a holy life, and be stingy with his money" (pp.70, 74 [66]). He confesses that initially those of them who:

Belong to the holiness movement grew up thinking that poverty was a great benefactor to holiness. Some of us were taught that to be holy you had to be poor. I have said, jokingly, that I must have been the holiest person in the church I attended because I was the poorest. I am personally thankful for the emphasis that has been put on prosperity, because it has changed my whole life (p.79).

From this assertion, it is glaring that even the known holiness churches are of recent beginning to preach prosperity but with caution in view of eternity. Example of this is the Deeper Life Bible Church founded by Pastor William Folorunso Kumuyi. He comments on this:

God delights in the prosperity of all His children (3 John 2). Our Salvation is not only about deliverance from sin; God also wants His own to enjoy abundant life, a life that triumphs over poverty, deprivation and shame. God is the only one who gives lasting riches but operates according to set laws Gen.8:22...Y You must Sow before you expect to reap...God commands giving because it is the surest way to getting (Kumuyi, 2010, p.2) [67]

It is no surprising therefore that the RCCG teaches prosperity to her members. This notwithstanding the ranks and files of the RCCG seek material blessings with puritanical attitudes and Heavenly consciousness.

\section{The Assemblies of God Church, Nigeria}

The Assemblies of God Church, Nigeria, is reported to have begun in 1930. It is the foremost classical Pentecostal church that bred the first generation of Pentecostals who "Exerted remarkable spiritual influence in Nigeria" (Achunike \& Kitause, 2013, p.6) [68]. This church belongs to the scriptura genre of Pentecostal churches in Nigeria which is not an indigenous church (Ukpong, 2008).

\subsection{Tithing, and Offerings in the Assemblies of God Church, Nigeria}

The classical Pentecostals in Nigeria appears to be the pacesetters in the faithful teachings and payment of tithes and offerings. It is probably through their practice of these obligations that the custom overspread all the other Pentecostal churches in Nigeria with great deal of modifications and attachments. The Assemblies of God Church preserves balanced teachings on the Biblical principles to prosperity through wilful giving without necessarily hypnotizing members to give. They teach prosperity side by side other scriptural themes, but leave the members with the option of either obeying the principles of giving and receiving. Hence not much has been written on prosperity by the leadership as well as the rank and file of the church to the knowledge of the present researchers. The book titled "Tithe: The History and Benefits" authored by the Reverend Israel Ndudim Nwokoro, the present superintendent of the Kogi District of the Assemblies of God Church, Nigeria remains the most informative on the subject from the church in Nigeria so far.

\subsubsection{Tithing}

The Assemblies of God Church teaches that "Tithe is Holy unto the Lord" (Nwokoro, 2007, p.38). Members are taught to pay their tithe promptly and correctly because "Tithe teaches us to fear God, Deut. 14:23" (Nwokoro, 2007, p.39). It is held that tithe payments demonstrate members' faithfulness to God. Tithes are not to be paid secretly. The church uses Num. 7:10-12 as their authority for this emphasis. Hence, tithe cards are introduced whereby every tither collects and records his/her tithe therein and at the point of payment, tithe 
payers are prayed for to receive God's blessings before the tithes are finally dropped in the tithe box. Details of individual's payment are documented in a ledger for official use.

The church gives teachings on the danger of defaulting on tithe payments. "Tithe defaulting is direct transgression of the law of God. Transgression of God's law is sin" (Nwokoro, 2007, p.43). Nwokoro is not alone in this view. According to Pirali (2010), "Sin is anything that displeases God; it is all unrighteousness" (p. 138) [69]. Nwokoro (2007) further admonishes:

Your tithe is not your Sunday school or your Church offering. It is not your pastor's gift. It cannot go as a levy for Church building. It is not even to be used for the burial of anyone; not even a part of it (pp. 43-44).

\subsubsection{Offering.}

The Assemblies of God Church keeps up four different offerings in addition to tithe payments and fund raising for any Church building or development project (T. Kandare, personal communication, May 3, 2013). These offerings include the under mentioned: (i). Sunday freewill offering (every Sunday), (ii). Missionary offerings (taken every first Sunday of the month side by side the Sunday offering), (iii). Needy offerings (taken for caring of the poor), and (iv).Thanksgiving offerings (taken when there is any thanksgiving by a member, group or the entire church).

\subsection{Seed Sowing in the Assemblies of God Church.}

The church seems to discourage the practice of seed sowing officially. However, some of their pastors are secretly indulging in it (R. Oguh, personal communication, May 2, 2013). It is uncertain why some pastors of the Assemblies of God Church, Nigeria have suddenly involved themselves in a practice that the church leadership abhorred. It is likely that these pastors in question are beginning to be influenced by the neo Pentecostal prosperity preachers in Nigeria. Whether this is true or not, the quick change in the attitude of some of the Assemblies of God Church pastors do as a matter of facts reveal some certain hidden truth unknown to the leadership of the Assemblies of God Church, Nigeria.

The fact is that all Pentecostal pastors do have common forum for interaction during every Pentecostal Fellowship of Nigeria (PFN)'s meeting. Some of them have become friends to the neo Pentecostal prosperity preachers and must have seen the way some of them do lavish money anyhow, live comfortably and cruise about with flashy cars. As human as they are, the Assemblies of God Church pastors might have started nursing some feelings of being left behind in terms of material things and are beginning to desire better condition of living, somehow like the way these prosperity preachers are living. Some of them must have also felt that in terms of theological educational attainment, the neo Pentecostal pastors may not have been better off than they are which might have led them to being inquisitive about the gap in their standard of living.

It is even worse when they find out to their dismay that some of their members are being captivated by the teachings and the acrobatic display of these prosperity preachers in Nigeria which probably triggers up the fear of the Assemblies of God Church pastors that their members may likely defect to those churches. This naturally has a snow ball effect on pastors' loyalty. This also might probably be the reasons for some of the Assemblies of God Church pastors to have started imitating the manners of life of the prosperity preachers in Nigeria. Nnamani (2007) seems to prove this point right when he said that the neo Pentecostal churches in Nigeria like the Living Faith Church are already overtaking the classical Pentecostals like the Assemblies of God Church in a supersonic speed, threatening to win the others over to their side. This notwithstanding, most avowed members of the Assemblies of God Churches seem to remain unshakable in their faith, appearing to resist any temptation to acquiring or accumulating earthly wealth in exchange for their souls. Also, it is an open secret to note that there seems to be more elderly pastors in the Assemblies of God Church than there are in the Living Faith Church and the RCCG.

\section{Benefits of Tithing in Christendom}

The study of this nature will be incomplete if no mention is made of the blessings that follow tithe payments as taught by its propagators in Nigeria. The Christian teaching on giving has always been a two-way traffic: "Give and it shall be given unto you" (Luke 6: 38). According to Mills (2009), "Giving money away increases the wealth of donor" (p. 99). Tithing, in the opinion of Prince (2001) "Is not for God's benefit; it is for our benefit... He is not asking us to give so that He can have; he is asking us to give so that we can have" (pp. 78-79). He maintains that through tithes and offerings, God pipes wealth to His people.

According to Cho (1987), "Tithing is a beautiful sacrifice" (p. 75) [70]. It is "God's modus operandi" (Prince, 2001, p. 85). So "Receiving begins with giving. There are no short cuts" (Stewart, n'd', p.89) [71]. Tithing, it is stressed, ever remains God's method of blessing His people (Hagin, 1995 [72]; Amaga, 2003 [73]). Studies conducted differently by eminent Pentecostals like: Nee, 1944 [74]; Copeland, 1974 [75]; Peale, 1993 
[76]; Amaga, 1997 [77]; Mahoney, 2002 [78]; Moses, 2006 [79]; Prince, 2007 and Agunwanba, 2007 [80] among several others identified so many blessings and benefits of tithing and offering for the obedient.

This article highlights the following:

1. Tithing removes a sense of guilt (Nwokoro, 2007).

2. Tithing releases a miraculous flow of God's blessings upon tithe payers (Mahoney, 2002).

3. Tithing removes curses, calamities and hazards from tithers (Nee, 1944).

4. Tithing makes one have boldness before God (Adjeman, 1995).

5. Tithing creates memory in the mind of God about the tithers (Moses, 2006).

6. Tithe payment brings super-abundant outpouring of all needed blessings on tithers (Kumuyi, 1998).

7. Tithe payment insures the practitioner of tithe of divine health and total safety (Peale, 1993).

8. Tithing makes tithers' heavenly account to grow very fat (Copeland, 1974).

9. Tithing removes inscrutable diseases from tithers (Agunwanba, 2007).

10. Tithing connects tithers to God's super abundant prosperity (Amaga, 1997; Prince, 2007).

11. Tithing documents tithers' faith in God (Murdock, 1998).

\section{Consequences of Tithing to Christianity}

The practice of tithing in Christianity is significant for the following reasons:

1. Abundance of "Meats in God's house" (Mal. 3: 10) so that the ministers serving God full time will have the means to take care of their own needs, Num 18:20-24 (Adjeman, 1995).

2. Tithe payments bring enough resources to take care of work in the house of the Lord (Adjeman, 1995).

3. Tithing helps in the furtherance of the Gospel (Douglas, 1985) [81].

4. Part of tithe proceeds goes for taking care of the poor, orphans and widows in the Church (Moses, 2006).

5. Tithing enables tithers to always remember and honour God in all their increase on earth (Mill, 2011).

6. Tithing delights the heart of the father in Heaven (Douglas, 1985).

\section{Evaluation of the Nigerian Pentecostals' Practice of Tithing and Seed Sowing}

Evaluation speaks of the worth or value of tithing and seed sowing through careful assessment of the practice among the Pentecostals in Nigeria. Tithing is ordained by God as revealed in this research work. Seed sowing is probably based on inference and personal revelations of its originators and practitioners across the globe and therefore remains Pentecostals' creation in Christendom. Tithing and Seed Sowing are wonderfully bringing proceeds and are tremendously assisting in the expansion of God's Kingdom here in Nigeria.

According to Pam (2013), the Pentecostal preachers who promote tithing and seed sowing:

Preach messages that give people hope such as "You can make it", "There is hope for the hopeless", "This is your season of harvest", "Year of your laughter", "Your turning point", "You are a star", "From nobody to somebody", "You are worshiping a rich God", "God will meet you at the point of your need" (p. 243).

He goes further to admit that these messages of the Pentecostals really spur the minds of the people that are in need. It is affirmed that some prosperity preachers do not only preach prosperity into the air, but they also show people the modalities and strategies and even Biblical principles on how to make it. To this, Ibrahim (2013) attests that "Many people have testified that it has worked out for them" (p. 243).

There is no doubt about Pentecostalism's great influence in every sphere of life in Nigeria through its theology of materialism. But this article wonders if some of the churches that preach prosperity have not drifted away from their ascetic focus and are now becoming more materialistic in practice. According to Lafarmcall (2009):

The scripture has warned us severally against the corrupting influence of money. Paul warned Timothy against the pursuit of money under the guise of God's work. He should be careful not to mix God's work with secret pursuit of money which some have done to their own destruction' (p.160) [82].

This citation reveals that some so called men of God are now taking cover in the name of God's work to enrich their pockets materially. The recent trend in most Pentecostal churches today seems to validate this claim beyond reasonable doubt. The way tithes and offerings are seriously being emphasized and promoted with hot separate exhortation before collections are made in churches raises doubt as to the genuineness of such offerings and also whether these preachers are not up to something else.

Times of offerings and seed sowing have been branded times of blessings and investment. According to Jibril (2012), "Most ministers hypnotize members and swindle them of their hard-earned resources in the name of sowing seed of faith for prosperity" (p. 2) [83]. But as have always been the case in Pentecostal circles, most of them always defend their actions. To Oyedepo (1992), "Money is the wheels on which the end time 
gospel will rotate round the world... Those who attack money in ministry and prosperity message do so under the devils influence" (p.195).

It is observed that to the Nigerian Pentecostals giving is only one-sided. There seems to be unfairness in the way cash flows in the churches in Nigeria. Gbile (2011) notes that:

What is lacking in the present day church is this fairness. There is not fairness amidst people again. The pastor is richer than everyone in the church. He displays his affluence. He gets many of the members to run around for him alone and does not consider this as unfair (p. 210) [84].

How the pastor gets richer than everyone else in the church is further captured by Gbile in these words: In many churches today, since pastors are used to raising offering every Sunday, the congregation has also come to understand that offerings are raised, not necessarily because God has asked for them but because it has become a custom. So, the people have also become very 'wise' now. They know that in every service, the pastor would raise two or three offerings. Therefore, they would determine that no matter what he says, they would not give beyond a certain amount. They change their high denomination currencies to smaller ones. When the Pastor calls them to dance forward and drop their offerings, the people would dance forward and drop a small amount of money. All the young men and ladies, who desire to go for disco dance but have not been able, now grab that opportunity and dance to their hearts content. As they dance forward and drop their little money, they go back, sit down, waiting for next round (Gbile, 2011, p. 181).

This lengthy quotation clarifies that not all the numerous offerings raised by pastors during every service are God's ordained. It intimates that some of the offerings are pastors' creation targeted towards the enrichment of the pastors other than the church itself or the members. It can also be deduced that not all the offerings and seed sowing attract the desired blessing or breakthrough as constantly being emphasised by pastors since the command to give is not coming from God Himself. It is also most probable that the offerings are becoming too frequent and too boring exercises that eventually make the people to start noticing that those collections are going into pastors' personal pocket otherwise the people would not have become suddenly wise in their giving. But whatever is the case, it is observed that most Pentecostal pastors especially all the presidents and founders of churches in Nigeria have really benefitted from this over stress on money. Ibrahim (2013) confirms that "The neo-Pentecostal prosperity gospel has gained and is still gaining ground in the country. Churches preaching prosperity gospel have spread all over the country and abroad" as a result of materialism (p.22).

Be that as it may, the payment of tithes in Nigeria has so many implications for Nigerian Christianity. Some people pay tithes to save face. Some people pay out of their religious conviction. Some others go out of their way to misappropriate money in their places of work to pay tithes. The notable case of a member of Believers Love World Inc otherwise known as Christ Embassy is a good case in point (Golddudu, 2013, p.1) [85]. Some people pay tithes and sow seed to boost their ego and to maintain their popularity within their Christian settings.

\section{Conclusion}

Tithing is an ancient scriptural custom which has been in use before the law and whose Biblical origin seems obscure. Tithing and seed sowing have become popularized with the advent of Pentecostalism because of the role they are currently playing in being perhaps the life wire of the church as its major sources of income. The Pentecostals of Nigeria by employing creativity and craftiness have designed their theology of prosperity to gained financial empire. Their constant promotion of breakthrough seminars and teachings which encourage cheerful giving to win a greater income in the future, whether such method is in line with the scripture or not, have succeeded in not only reawakening the interest of the mainline churches toward tithing, but have equally been seen to influence even, the theology, stability and commitment of the classical Pentecostals' pastors and members.

It is discovered that there is at present, a paradigm shift in the usage of tithe proceeds from the old system of channelling it to taking care of only the priests to the modern multi-purpose usage. Unlike before, the modern day preachers are in the perpetual habit of scheming to get money out of people under different named offerings by hypnotizing them (Ugwueye, 2002). This practice has tremendously enriched Nigerian Pentecostal pastors in no small measure.

As revealed, most of the prosperity preachers in Nigeria have undermined teachings on holiness and are now in quick pursuit of materialism. The paper did not lose sight of the fact that there are still some handfuls of Pentecostal preachers that are uncompromisingly preaching sound doctrines, steadily living puritanical lifestyle, and are enthusiastically modelling their followers to adopt same in Nigeria. It recommends among other things that those Pentecostal prosperity preachers in Nigeria who over do prosperity preaching should be 
called to order for the sake of Jesus Christ, the founder of Christianity, the Saviour.

\section{References}

[1]. Ibenwa, C.N. (2012). "The Church and Tithe in the Contemporary Society" in International Journal of Christian Theological Research, Vol. 2, No. 1.pp. 12-23

[2]. Achunike, H.C. (2007). "Prosperity preaching in the Nigerian Religious Space" in Nigerian Journal of Social Sciences (NJSS) Vol.4, No.1, pp. 83-96.

[3]. Nnamani, A.G. (2007), "The Ambivalent Impact of Pentecostalism on Enculturation" in Nnamani, A.G. (ed.). The New Religious Movements: Pentecostalism in perspective, Benin City: Ava Publishers, pp. 234-251.

[4]. Watkins, M.G. \& Watkins, L. I. (ed.), (1992), All Nations English Dictionary. Katunayake, Sri Lanka: New Life Literature (PVt) Ltd.

[5]. Inyama, T. (2003). Principles of Financial Prosperity, An unpublished study Notes, Pilgrims Theological Seminary, Lagos, Taraba Study Centre.

[6]. Oyedepo, D.O (2010). The Miracle Seed. Rep., Lagos: Dominion Publishing House.

[7]. Redeemed People's Mission Inc (2003). Membership Manual. Jos: Fab Ameh(Nigeria) Ltd.

[8]. Hornby, A. S. (2006). Oxford Advanced Learner's Dictionary, $7^{\text {th }}$ edition, New Oxford University Press.

[9]. Ball, A.E. (2003). Let us Give: Scriptural Reflections for Introducing Offerings, Grand Rapids: Kregel Publications.

[10]. http://www.ask.com/answer/10233161 Retrieved on $28^{\text {th }}$ April, 2013

[11]. en.wikipedia.org/Wikipedia/sowing Retrieved on $12^{\text {th }}$ May, 2013

[12]. http://www.sowingseedsoffaith.com Retrieved on $6^{\text {th }}$ May, 2013

[13]. Roberts, O. (1970). Miracle of Seed-Faith, Tulsa, Oklahoma: Abundant Life Publications.

[14]. roberts, O. (1985). Attack Your Lack. Tulsa, Oklahome: Abundant Life Publications.

[15]. Adeleye, F.B. (2011). Preachers of a Different Gospel, Bukuru: ACTS Bookshop.

[16]. http://www.Docities.org/mikespieceofheaven4/tithingseedsowing.htm Retrieved on $6^{\text {th }}$ May, 2013

[17]. Unger, M.F. \& Harrison, R.K. (ed.), (1988). The New Unger's Bible Dictionary, Chicago: Moody Press.

[18]. Douglas, J.D. \& Tenney, M.C. (ed.), (1987). New International Bible Dictionary Based on the NIV, Grand Rapids; Michigan: Zondervan Publishing House.

[19]. Kumuyi, W.F. (1996). Complete Bible Study Series in One Volume, $6^{\text {th }}$ ed., Lagos: Life Press Limited.

[20]. Lindsay, G. (1996). God's Master key to Prosperity, Rep., Dallas, Texas: Christ For the Nations Inc.

[21]. Mill, D.H. (2009). Why Non-Tithing Christians Become Poor... and How Tithing Christians Can Become Rich. Benin City: Hosanna Christian Bookshop \& Publishing House.

[22]. Nwokoro, I.N (2007). Tithe: The History and Benefits, Lokoja: Chriso printers.

[23]. Dietlein, D. (1967). "Tithes" in New Catholic Encyclopaedia Vol. 14, New York: McGraw-Hill Book Company. Pp. 174-175

[24]. Walter, M. (1997). The Kingdom of the Cults, Minnesota: Bethany House Publishers.

[25]. MacArthur, J.F. (1992). Charismatic Chaos, Grand Rapids Michigan: Oasis International Ltd.

[26]. Mumford, D.J (2012). “Exploring Prosperity Preaching” Retrieved fromIrforasteros.com/2012/06/12. On $8^{\text {th }}$ May, 2013.

[27]. Okwori, E.M. (1995). Godliness for Gain: An Evaluation of the Nigerian Version of the Prosperity Gospel, Jos: Capro Media Services.

[28]. Hummel, C.E. (1991). The Prosperity Gospel, Downer Grove: Intervarsity Press.

[29]. McIntyre, J. (1997). E.W. Kenyon and his Message of Faith: The True Story. Kaduna: Evangel Publishers Ltd.

[30]. McConnell, D.R. (1995). A Different Gospel, Massachusetts: Hendrickson Publishers, Inc.

[31]. Onwu, E.N (2006). "Poverty and Prosperity in Nigerian Pentecostal Theology:A New Testament Critique" in Journal of New Testament Research Volume 1, December 2006. pp. 15-26.

[32]. Pam, G.D. (2012). A Compendium of Theology, Jos: Sele Printing and Publishing House.

[33]. Ibrahim, B. (2013). "The Theology of the Cross: A Stumbling Block to the Neo-Pentecostal Gospel" in TCNN Research Bulletin, No. 58 March 2013). pp. 16-28.

[34]. Ojo, M.A (2012). "Consonance and Dissonance in the Doctrinal Emphasis of Prosperity among Nigerian Pentecostal" A paper presented at the Nigerian Centre for Pentecostal and Charismatic Studies (NPCRC) Conference, in Abuja, 23-27 May, 2012.

[35]. Emeka, P. (2002). The Benson Idahosa Factor in Nigeria Pentecostalism, An Unpublished Ph.D Thesis University of Nigeria, Nsukka.

[36]. oyedepo, D.O (2008). Pillars of Destiny, Lagos: Dominion Publishing House.

[37]. oyedepo, D.O (1995). The Hidden Covenant of Blessings. Lagos: Dominion Publishing House.

[38]. Adjeman, G.K.A. (1995). Tithing: Your Passport to God's Abundance, Lagos: Dominion Publishing House.

[39]. Oyedepo, D.O (2010). Breaking Financial Hardship, Lagos: Dominion Publishing House.

[40]. Oyedepo, D.O (1997). Showers of Blessings, Lagos: Dominion Publishing House.

[41]. Ugwueye, L.M. (2002). "Religiosity Without Religion: A Survey of the Decay in God's House Today" in Ugwu, C.O.T. (ed.). Corruption in Nigeria: Critical Perspectives, Nsukka: Chuka Educational Publishers, pp. 221-229.

[42]. oyedepo, D.O (2007) . Possessing your possession, Rep., Lagos: Dominion Publishing House.

[43]. Oyedepo, D.O (2005). Understanding Financial Prosperity, Lagos: Dominion Publishing House.

[44]. Oyedepo, D.O (2007). Success System, $3^{\text {rd }}$ ed., Lagos: Dominion Publishing House.

[45]. Murdock, M. (1998). 7 keys to 1000 Times More, Texas: Wisdom International.

[46]. Idahosa, B.A. (1998). 1001 Divinely Inspired Sayings, Benin City: Rainbow House Publishers.

[47]. Oyedepo, D.O (2010). Covenant Wealth, Rep., Lagos: Dominion Publishing House.

[48]. Ukpai, U. (2011). Supernatural Abundance, Uyo: The Victory Publishers.

[49]. Oyedepo, D.O (2004). Exploring the Secrets of Success, Rep., Lagos: Dominion House.

[50]. oyedepo, D.O (2011). All You Need To Have All Your Needs Met. Rep., Lagos: Dominion Publishing House.

[51]. oyedepo, D.O (2004). Exploring the Riches of Redemption. Lagos: Dominion Publishing House.

[52]. Mill, D.H. (2011). Name it Claim it Take it. $6^{\text {th }}$ edition, Accra: Parchment House.

[53]. Redeemed Christian Church of God (RCCG) Inc. (2011). 2011 Holy Ghost Congress Programme of Events, Lagos: The Directorate of Christian Education, RCCG.

[54]. Adeboye, E.A. (2003). Behold He Cometh, Lagos: Christ the Redeemer's Ministries.

[55]. Ukpong, D.P. (2008). Nigerian Pentecostalism: Case, Diagnosis and Prescription, Uyo: Fruities' Publication.

[56]. Redeemed Christian Church of God (RCCG) Inc. (2003). Believers Class Manual, $7^{\text {th }}$ ed., Lagos: The Directorate of Christian Education, RCCG. 
[57]. Redeemed Christian Church of God (RCCG) Inc. (2011). Baptismal Class Manuel, Abeokuta:The Directorate of Christian Education, RCCG.

[58]. Redeemed Christian Church of God (RCCG) Inc. (2009). Sunday school Teachers' Manual 2009/2010 Edition, Lagos: The Directorate of Christian Education, (RCCG).

[59]. adeboye, E.A. (2011). Austerity to Prosperity, Rep., Lagos: Christ the Redeemer's Ministries.

[60]. adeboye, E.A. (2005). The Ultimate Financial Breakthrough, Lagos: Church Media Services Limited.

[61]. adeboye (2000). The Blessings of Abraham, Lagos: Christ the Redeemer's Ministries.

[62]. adeboye, E.A. (2002). Sermons on the 2001 Holy Ghost Services, Lagos: F. \& J. Publishing and printing.

[63]. Redeemed Christian Church of God (RCCG) Inc. (2011). 2011 Training Weekend (Basic Biblical Doctrines R-Examined), Lagos: The Directorate of Christian Education, RCCG.

[64]. Prince, D. (1986). God's Plan for your Money, Charlotte: Derek Prince Ministries.

[65]. Fomum, Z.T. (1988). The Christian and His Money, Lagos: Conquest Communications

[66]. Hill, W. F. (2002). What Is Holiness, $7^{\text {th }}$ edition. Kumba: Son of Miracle Publication.

[67]. Kumuyi (2010). "Prove God Now" in Christian Women Mirror (The Law of Harvest), Lagos: Life Press, p.1.

[68]. Achunike, H.C \& Kitause, R.H. (2013). "Pentecostal Theology and Ethics in the Nigerian Society". A paper presented during the $28^{\text {th }}$ Conference of the Catholic Theological Association of Nigeria (CATHAN) held at Madonna Renewal Centre (Immaculate Heart Sisters) Nkpo-Onitsha between $2^{\text {nd }}$ and $5^{\text {th }}$ April, 2013.

[69]. Pirali, A. (2010). Prosperity God's Way, No town: Exulon Elite.

[70]. Cho, D.Y. (1987). Salvation, Health \& prosperity, Umuahia: Christian Crusaders.

[71]. Stewart, D. (n.d.). Miracle Success: How You Can Have It, Benin City: Calvary Publications.

[72]. Hagin, K. E. (1995). Biblical Keys to Financial Prosperity, Tulsa: Kenneth Hagin Ministries.

[73]. Amaga (2003). Powers for Uncommon Success, Lagos: Faith Publishers.

[74]. Nee, W.C. (1944). Financial Strategies from Heaven, Benin City: Assurance Christian Publications.

[75]. Copeland, K. (1974). The Laws of Prosperity, Texas: Kenneth Copeland Publications.

[76]. Peale, N.V. (1993). How to Multiply your Blessings, Lagos: African pastors Literature Trust.

[77]. amaga, S. (1997). Super Abundance Prosperity, Port Harcourt: Faith Publishers.

[78]. Mahoney, R. (2002). The Shepherd's Staff, San Fernando Bird: World Map Press.

[79]. Moses, A. (2006). Operating on the Economy of Heaven, Jalingo: Integrity Library \& Book Publications.

[80]. Agunwanba, J.C. (2007). Prosperity God's Way, Ibadan: Scripture Union (Nig) Press \& Books Ltd.

[81]. Douglas, A. (1985). One Hundred Bible Lesson, Jos: Chris Onogunwe \& Family Bible House

[82]. Lafamcall (End-time) Ministries (2009). A Book on Divine Blessing, Ibadan: Oluseyi Press Ltd.

[83]. Jibril, W. (2012). "The Proliferation of Churches in Nigeria", Retrieved from http://www.thenigerianvoice.com On $13^{\text {th }}$ Oct. 2012.

[84]. Gbile, A. (2011). Tapping God's Resources for Life And Ministry, Rep., Gboko: Peace House Press.

[85]. Golddudu, M. (2013), "Christ Embassy Pastor, Chris Oyakhilome in \$35million Laundering Scam", Retrieved from: www.nairaland.com/55920/christ-embassy-pastor-chris-oyakhilome on $23^{\text {rd }}$ November, 2013. 